\title{
New Challenge and Perspectives of Educational Lexicography: Phraseological Dictionary-Game in Paper Format
}

\author{
Nikitina T.G. \\ Pskov State University \\ Pskov, Russia \\ cambala2007@yandex.ru
}

\author{
Rogaleva E.I. \\ Pskov State University \\ Pskov, Russia \\ cambala2007@yandex.ru
}

\begin{abstract}
The article presents innovative concept of educational phraseological dictionary-game in a form of a quest. Native and foreign experience of educational literature creation in a format of a book-game is summarized. The aim and objectives of the presented in the article dictionary project of Experimental laboratory of educational lexicography of Pskov State University are defined.Dictionary-quest "All in the bag" is organized as a narrative text, where the origin of phraseological units, study fairytale and real heroes together with the readerchild. Apart from the main objective - educational representation of Russian phraseology at a wide cultural-historic background, the authors solve the problem of general level of a child's erudition increase. Macrostructure of a dictionary and parametric model of dictionary article corresponds with the demands, placed on educational quest creation. The article describes its stages and levels, plot, navigators and tasks for progress. We summarize the work of a reader with the dictionary article. We also present the results of the teaching experiment, held at schools of Pskov according to the materials of the dictionary-quest, which prove the effectiveness of created methodology of dictionary representation of phraseology and practical value of the dictionary, recommended by methodical committee of educational technologies faculty at Pskov University for introduction into training junior school teachers.
\end{abstract}

Keywords-educational lexicography; phraseological dictionary; book-game; dictionary-quest; dictionary article; pedagogical experiment.

\section{INTRODUCTION}

Nowadays books-games become more popular and not only created with the help of multimedia technologies, but also published in paper format. This conditions the necessity to form new approaches to dictionary texts construction, productive methodologies of influence on a reader creation, including in terms of game models of the text.

Taking this into account, we consider it urgent to use game technologies of lexicographic texts construction, including techniques adaptation of books-games to paper format during our lexicographic concept realization, as it is the most important ways of educational phraseological dictionary interactivity induction. The aim of this article is to present this lexicographic approach, which corresponds not only with the demands of a reader, but also real state of things in the sphere of modern communication.

\section{LITERATURE REVIEW}

As it is known, a book-game provides a reader's participation in the plot formation. The reader is offered to become the hero of the book, make these or that decisions and move from situation to situation, from the unit o unit.

In the opinion of O. Chebennev and A. Zilbernshteyn [12], a book-game as a genre phenomenon started to form with the story of Jorge Luis Borges "Examen de la obra de Herbert Quain" (1941). In this story there were plot lines and readers could come to one of nine different ends.

In 50-s of the last century this idea was used in teaching by the American psychologist Burrhus F. Skinner, who created the series of teaching books under general title "The Tutor Text". There were texts with questions and several variants of solutions in these books. In France the group of writers "Oulipo" worked in the genre of a book-game, or how it was called "tree-like literature". Their first book "History of your way" was a full-fledged interactive novel with a lot of plot crutches.

Real popularity of books-games started with the project by E. Packard and R. Montgomerie "Choose Your Own Adventure". This biggest series (within 20 years there were 184 items) had a simple system of rules, was created for children at the age of 10-14 and was very popular [12].

In Russia books-games were actively published during the second part of 1990-s. The most popular authors of this genre are the following: D. Braslavskit [2] and V. Shuvalov [13,14].

In terms of computer technologies development popular become books-games, which exist in internet-format. It is explained by their connection with computer games and interest decrease among young people, who are the main targeted audience of books-games, in the literature in a form of a book [8]. Here great popularity has Russian portal 
connected with books-games creation "Quest-Book", where each visitor of the site can create own literature project independently or with other authors. Readers can positively or negatively estimate the books, write comments, create discussions of the read books. The most popular are detective stories and fantasy.

On the other hand, multimedia technologies development leads to the fact that since 2009 they start to be used during paper interactive books creation [5]. Video-in-Print technology helps to include video into letterpress. Some publishing houses issue books for children with "magic pens": if you pass the pen over the page, the book would tell the story and give tasks.

Books without computer technologies use also can be interactive. For example, the book-game "Live book" by E. Tyulle [11], in which the author interacts with small readers with the help of yellow, red and blue circles.

Mobile gadgets and audio books popularity increased the interest of children in reading. The latest research works concerning this problem in Russia show positive dynamics in the sphere of children reading in comparison with 2000-2010, when there was complete refusal of reading. Nowadays many junior and senior schoolchildren read scientific-cognitive literature, preferring encyclopedic sources [4].

Taking this tendency into account nowadays in the Experimental laboratory of educational lexicography of Pskov State University interactive phraseological dictionaries are created in a paper format for junior and mid age schoolchildren [6], [7].

These dictionaries are not only the first scientifically substantiated educational representation of Russian phraseology, which guarantees successful phraseological unit mastering by a child [9], but becomes the door into the world of Russian culture and history.

Nowadays the workers of the laboratory solve the problems of a book-game-phraseological dictionary-quest creation, the experience of which creation is presented below.

\section{RESEARCH METHODOLOGY}

During language material study in order to realize its adequate parameterization in terms of dictionary article we used semantic identification techniques and linguisticculturological analysis of phraseological units, methodology of structural-semantic modeling and descriptive method.

In order to realize author's conception of an interactive dictionary representation of phraseology to a child we used lexicographic method of discursive hypertext construction using the tactics of etymological paraphrasing.

During phraseological dictionary-game construction in a genre of a quest the workers of the Experimental laboratory of educational lexicography of Pskov University took into account the demands placed on educational quest creation, offered by E. A. Igumnova, I. V. Radetskaya [3].

1.Quest title: All in the bag: cognitive-playing phraseological dictionary with adventures.
2.The aim of the quest: getting schoolchildren acquainted with communicatively important Russian phraseological units in a wide context of the Russian culture and history.

3.The objectives of the quest: schoolchildren's language and linguistic-culturological knowledge formation, their cognitive activity development, general worldview broadening, speech culture improvement.

3.Duration, volume: 15 dictionary articles (they are created in a form of plot stories), 15 stages of a quest, each of which includes several levels: grammar features and semantics of phraseological unit mastering, history of its origin, observing functioning of a phraseological unit, its use in different speech situations, creative tasks.

\section{Age of the readers: 7-12 years-old.}

5.Legend: characters-narrators, who present phraseological units to a reader, gather in Pushkin mountains because of unknown character's invitation Pushkin'sphantom and take part in a toss: taking the lot from the hat, they have to know, who will become the narrator of the phraseological unit (All in the bag) history.

6.Theme in task: phraseological - together with the heroes-narrators reconstruct etymology of phraseological units; culturological: pick and master information about hats of different times and nationalities (one of the charactersnarrators, clothes designer Santimetrenko lost the hats, which he wanted to show at the exhibition, they scattered in the dictionary and the reader has to pick them and find their description in mini dictionary- appendix). plotline:

7. Plot: plot stories of the separate articles form general

- "And who knows? Pushkin?" - in this article a child together with the authors gets to the party of Pushkin poetry and searches for the first narrator, who turns out to be a dictionary.

- "As fast as one can "-in this article together with the authors the reader sits into the cart and goes to the excursion over forest paths of Pushkin Reservation. Cabman turns out to be a dog and its friend hare - Gafik and Senya. They tell the story of the phraseological unit origin, connected with body of a horse and the peculiarities of its running.

- "Things could be better" -in this part the story of a real character- "Bugrovo" museum complex keeper Vyacheslav Yurevich Kozmin, changes into a fairy tale and the story is continued by a peasant stove.

- "You can't get it for love or money" - in this article readers, authors and narrators search for one of lost by Santimetrenko hats in the afternoon, Pushkin phantom brings the candle in order to demonstrate the phraseological unit.

- "Second cousin twice removed"- the action is in Mikhaylovskoe. Here the narrator of this phraseological story Raskopkin asks the participants of the quest to pick video material about fences, which will help in explaining the etymology of the phraseological unit. 
Characters choice, as a rule, is explained by their connection with the story of the phraseological unit origin: the phraseological unit "more dead than alive" is explained by doctor Vitaminkin, phraseological unit "come after the fair" is explained by Little Red Riding Hood, the witch Baba Yaga explains the phraseological unit "to feel spite toward" and etc.

- "All in the bag" - in this final part the narrator becomes the reader-child, who got the toss, he should say the history of the phraseological unit himself.

He receives congratulations:

If you came to this article owing to the cube, our congratulations, you are the winner of a phraseological quest! You have mastered 15 most popular Russian phraseological units and now can use them in speech. How many phraseological units are there in the Russian language? - More than 30000 !

\section{That is why:}

\begin{tabular}{|l|l|l|l|l|l|l|l|l|l|l|l|}
\hline A & B & Zh & V & D & G & D & E & Ye & Yo & P & Zh \\
\hline 3 & P & I & O & Y & D & K & L & O & M & N & O \\
\hline П & P & L & S & T & U & Zh & F & H & Ye & Ts & Ch \\
\hline H & Sh & Shch & - & I & H & - & A & Ya & Ю & ! & Ya \\
\hline
\end{tabular}

\section{Tasks (challenges) for moving according to the plot.}

At the first level of the quest the reader starts to fulfill interesting tasks checking his erudition level. If there are some difficulties he gets help. For those, who wants to know, the next level is "Interesting facts" column from a Clever hat. The instruction concerning these and other tasks fulfillment the reader gets in Introduction. Let's see its fragment:

Do you want to write something in the dictionary with your pen, draw and paint? You are welcome! For this purpose we have the following tasks.

Do you want to be famous in whole Russia and your name to be written in the next publication of the dictionary? Then fulfill the tasks with the sign (the image of a letter is given) and send us e-mail to dety-frazeologiya@ya.ru .

\section{Navigators.}

A) Columns of the article - "Banner", "Phraseological story", "Phraseological observation point", "Speech laboratory", "Childlore", "Creative workshop", "Everybody to the stadium".

B) "Phraseological glass fragments". Navigator is introduced in the introduction: During going through the stages of our intellectual phraseological quest you will get surprises. If you fulfill the tasks of "Phraseological kaleidoscope" and find the letter-glass fragment at a necessary page, write it into the frame at page 154 . When you collect 7 letters-glass fragments, our dictionary will say you something really important! (The letters should form the word "molodets" (Well done!))

C) The playing block at the end of the article. According to the number of dots at the seen sides of the block (some arithmetic actions should be carried out with it) a reader sees to which article he has to go, finding it according to the corresponding number in the contents.

9. The result of the quest -all stages of the quest and the levels at every stage (the presented in the dictionary communicatively valuable and cultorologically important Russian phraseological units are mastered) are realized; cultorological information on the topic "Hats" is gathered. All hats are found and information about them is received from the dictionary; glass fragments of "Phraseological kaleidoscope" are gathered and the reader's activity is estimated ("molodets"-Well done!).

\section{RESULTS}

In order to check the effectiveness of created methodology of educational phraseology representation in format of the dictionary-quest we held the pedagogical experiment. 20 children at the age of 8 with general speech disorders took part in the experiment (pupils of schools in Pskov).

In order to characterize the initial level of phraseological units mastering (semantics of PU understanding, inner form realization, the main word semantic understanding, correct use in speech) we held the questionnaire: concerning each phraseological unit (at top speed, when pigs fly, second cousin twice removed, miracles will never cease!) students were offered several questions:

1. Have you ever heard such an expression?

2. What does this expression mean?

3. In which cases, situations do people use this expression? Give examples.

4. Name the words in this expression, which you don't understand.

During the level of phraseological unit mastering by junior schoolchildren we used the following criteria:

O level - students don't understand the semantics of the phraseological unit, can't use it in speech, don't understand the meaning of all key words in a PU.

1 level-students understand the semantics of the phraseological unit, can't use it in speech, don't understand the meaning of all key words in the PU.

2 level - students understand the semantics of the phraseological unit, make mistakes in using PU in speech, don't understand the meaning of all key words of a PU.

3 level -students understand the semantics of the phraseological unit, make mistakes in PU use in speech, know the meaning of the key word.

4 level - students understand semantics of the phraseological unit, can use PU in speech, know the meaning of the key word of a PU.

As a result of children's answers analysis it turned out that all students have the initial (0) level of mastering phraseological units.

Then we divided students into two groups, each group included 10 people. 
With the first experimental group (E-1) we worked with dictionary-quest "All in the bag" (students fulfilled tasks of lexicographical quest individually and collectively) during two months at the "Club of the Russian language experts" at the Experimental laboratory of educational lexicography in Pskov State University. The other group of schoolchildren (E-2) studied phraseological units according to other phraseological dictionaries for junior schoolchildren [1], [10] and others. After the experiment teaching final questionnaire was held, the results of which were the following: in group E-1, which worked with the dictionary-quest, 9 people $(90 \%)$ had the $4^{\text {th }}$ level, $1(10 \%)$ had the $3^{\text {rd }}$ level. In group E-2 the results were the following: 1 person $(10 \%)$ had the $1^{\text {st }}$ level, 3 people(30\%) had the $2^{\text {nd }}$ level, the $3^{\text {rd }}$ level had $6(60 \%)$ people. Nobody had the $4^{\text {th }}$ level.

The received results prove that the innovative concept of educational phraseology representation in a format of a dictionary-quest can be acknowledged effective. The results of the experiment were discussed at humanitarian education theory and methodology department at PskovSU and are recommended by the methodical committee of educational technologies department for introduction into practice of training and retraining of primary school teachers. Practical value of the held research and the created concept is in the fact that phraseological dictionary-quest can be used at primary school at the Russian language lessons and during extracurricular activity for family reading and while teaching bilingual children Russian.

\section{CONCLUSION}

Thus, the results of our research prove that the idea of the book-quest can be realized in a format of educational dictionary. Studying phraseological material as the object of description in this new playing dictionary is explained by cultural markedness, semantic figurativeness and expressiveness of phraseological units.

It is possible to reveal these qualities of a phraseological unit and transfer them to the reader in a form of playing plot educational-scientific text.

The results of the experimental Russian phraseology teaching among junior schoolchildren with the help of "All in the bag" dictionary-quest not only proved the effectiveness of the created lexicographic concept, but also showed the advantages of this dictionary as the means of teaching in comparison with other phraseolofgical sources, addressed to junior schoolchild.

\section{References}

[1] Basko N.V. Phraseological dictionary. Why do we say so? (1-4 grades). Moscow: AST-PRESS BOOK. 2011, 192.

[2] Braslavskiy D.Yu. Subterranean of Black castle. Moscow: AT. 1991, 223.

[3] Igumnova E.A., Radetskaya I.V. Quest-technology in education: manual for students of higher educational establishments and colleges. Chita: ZabSU. 2016, 164.

[4] Kolosova E.A. Consumers socialization of children: approaches and practices. Childhood of the XXI century in social-humane perspective: new theories, directions and notions. Moscow: ROS. 2017, pp. 139158.

[5] Mitsuk T.I. Multimedia technologies influence on the ways of presentation of electronic and paper book . Connect-Universum - 2014: collection of materials of the $\mathrm{V}$ International scientific-practical internet-conference. 2015, pp. 166-176.

[6] Nikitina T.G, Rogaleva E.I. Innovative approaches to educational phraseological dictionary construction as an integrative hypertext. Society. Integration. Education. Proceedings of annual international scientific Conference. Volume II, May, 22-23, 2015. Rēzekne: RēzeknesAugstskola. 2015, pp. 175-183.

[7] Nikitina T.G., Rogaleva E.I. Manual in phraseology as the means of liugual-country study competence formation among foreign students. Society. Integration. Education. Proceedings of annual international scientific Conference. May, 27-28, 2016.Vol. 1. Rēzekne: RēzeknesAugstskola. 2016, pp. 188-199.

[8] Puchkova S.A. Book-game as genre phenomenon. World literature from the point of view of modern youth: collection of materials of the International student scientific-practical conference. 2016, pp. 134-140.

[9] Rogaleva E.I. Modern educational phraseography: theory and practice. Pskov: LLC LOGOS Plus. 2014. 344.

[10] Roze T. V. Big phraseological dictionary for children. Moscow: OLMA Media Group. 2005, 224.

[11] Tyulle E. Live book. Moscow: Klever Media Group. 2014, 54.

[12] Chebeneev O., Zilbernshteyn A. Adventures, where are you - hero. The world of phantasy. 2012, 104, pp. 54-67.

[13] Alexsandr S. Kuznetsov. Russian Professor's meeting. Russian Journal of Physical Education and Sport. 2019, 14(1), pp. 17-22. DOI: 10.14526/2070-4798-2019-14-1-18-24

[14] Shuvalov V. Koshchey’s chain. Perm: Yanus. 1992, 143. 